\title{
Diskursus Gender dan Dakwah di Era Revolusi Industri 4.0
}

\author{
Uswatun Niswah \\ Universitas Islam Negeri (UIN) Walisongo Semarang \\ uswatun_niswah@walisongo.ac.id
}

\section{Article Information}

\begin{tabular}{llll}
\hline Submitted & $: 2021-05-27$ & Revision & $: 2021-11-23$ \\
Reviewed & $: 2021-11-18$ & Published & $: 2021-11-30$ \\
\hline
\end{tabular}

\begin{abstract}
The Industrial Revolution 4.0 Era is a golden opportunity for woman to develop their potential to be equal to men in various fields. This paper aims to discuss the history of feminists in fighting for gender equality both globally and in the development of gender discourse in Indonesia. In realizing gender equality, women empowerment programs need to be presented in unique, innovative, and creative way according to women's needs. Gender and Da'wah Discourse in the Industrial Revolution 4.0 Era can be realized in the form of da'wah for the women empowerment through education or training with community-based, so that women can carry out their roles proportionally and professionally. Da'wah for the women empowerment in the industrial revolution 4.0 era is expected to be able to invite, foster and guide women to develop their potential to be able to be productive, creative and financially independent without having to leave their roles as an individual, wife and mother. Da'wah for women empowerment as an effort to achieve gender equality need to pay attention to the segments and needs of each group of women being fostered, such as the community of young women, the community of housewives and the community of career women.
\end{abstract}

Keywords: Industrial Revolution 4.0 Era, Gender, Da'wah, Women Empowerment.

Abstrak:Era Revolusi Industri 4.0 merupakan peluang emas bagi perempuan untuk
mengembangkan potensi diri agar setara dengan laki-laki di berbagai bidang. Tulisan
ini mendiskusikan tentang sejarah kaum feminis dalam memperjuangkan kesetaraan
gender baik secara global maupun dalam perkembangan diskursus gender di Indonesia.
Agar terwujud kesetaraan gender, tentu diperlukan program-program pemberdayaan
perempuan yang dikemas secara unik, inovatif dan kreatif sesuai dengan kebutuhan
perempuan. Diskursus gender dan dakwah di era revolusi industri 4.0 saat ini bisa 
diwujudkan dalam bentuk dakwah pemberdayaan perempuan melalui pendidikan atau pelatihan berbasis komunitas agar para perempuan dapat menjalankan perannya secara proporsional dan professional. Dakwah pemberdayaan perempuan di era revolusi industri 4.0 ini diharapkan mampu mengajak, membina dan membimbing perempuan untuk mengembangkan diri dan potensinya agar mampu produktif, berkarya dan mandiri secara finansial tanpa harus keluar dari orbitnya dan mengingkari perannya sebagai individu, istri dan ibu. Dakwah pemberdayaan perempuan sebagai upaya dalam mewujudkan kesetaraan gender harus melihat segmen dan kebutuhan dari setiap kelompok perempuan yang dibina seperti komunitas remaja putri, komunitas ibu rumah tangga dan komunitas perempuan karier.

Kata kunci: Era Revolusi Industri 4.0, Gender, Dakwah, Pemberdayaan Perempuan.

\section{Pendahuluan}

Gender memang bukan merupakan isu baru dalam diskursus kajian keilmuan, baik di Indonesia maupun pada tataran global. Namun isu gender masih selalu menjadi topik kajian yang menarik. Karena membincang persoalan gender akan membutuhkan beragam sudut pandang untuk melihat dan menganalisisnya. Diskursus gender hingga saat ini, tak kunjung menemui titik temu untuk menyatakan satu kesepatan tentang konsep, ideologi, maupun problematika mengenai gender itu sendiri. Hal ini semakin akut, manakala muncul penilaian bahwa isu gender sengaja dihembuskan oleh negara-negara Barat ke dalam dunia Islam.

Meski gender tidak bersifat universal, namun hierarkhi gender bisa dikatakan universal. Berbicara mengenai gender, sudah pasti berkaitan dengan gerakan feminisme. Karena berawal dari gerakan feminis itulah ketimpangan hak-hak perempuan yang dinilai tidak adil jika dibandingkan dengan laki-laki mulai digugat, dan dipersoalkan. Para feminis menuntut persamaan hak dan kesetaraan gender antara laki-laki dan perempuan dalam berbagai bidang kehidupan. Di era revolusi industri 4.0 saat ini hampir tidak ada perbedaan dan sekat ruang aktifitas antara lakilaki dan perempuan untuk maju dan sukses dalam berkarya maupun berprestasi bahkan untuk menempati posisi yang sama di berbagai bidang. Sebagaimana dikatakan Gandhi (2002:5) bahwa kaum perempuan adalah mitra kaum pria yang diciptakan dengan kemampuan-kemampuan mental yang setara. Kaum perempuan mempunyai hak penuh untuk berpartisipasi dalam aktivitas-aktivitas kaum pria, dalam detail yang sekecil-kecilnya. Kaum perempuan juga memiliki hak atas kemerdekaan dan kebebasan yang sama seperti yang dimiliki kaum pria. Kaum 
perempuan berhak untuk memperoleh tempat tertinggi dalam ruang aktivitas yang dia lakukan, sebagaimana kaum pria dalam ruang aktivitasnya .

Meski usaha kaum feminis dalam memperjuangkan kesetaraan gender sudah menampakkan hasil di berbagai bidang. Namun pertanyaan yang muncul kemudian adalah apakah prestasi gerakan feminisme tersebut akan membawa dampak kepada terciptanya dunia yang tanpa eksploitasi, dominasi, hegemoni dan penindasan? Atau malah sebaliknya, akan mendorong perempuan untuk bergerak keluar orbit dengan mengingkari kodratnya? Diskursus gender dalam berbagai perspektif ini memang terus bergulir. Oleh karena itu, untuk mewujudkan pengarusutamaan gender dalam berbagai diskursus ini diperlukan kegiatan dakwah yang dikemas dalam program pemberdayaan perempuan. Melalui dakwah pemberdayaan perempuan ini diharapkan akan mampu memberdayakan perempuan agar bisa melaksanakan perannya secara seimbang dan professional, bisa berkarya dan berprestasi setara dengan laki-laki di berbagai bidang tanpa harus kehilangan arah dan koridor sesuai dengan ajaran dan nilai-nilai Islam. Sehingga para perempuan mampu berdaya tanpa kehilangan jati diri dan mengingkari takdirnya sebagai perempuan, ibu, istri dan masyarakat. Tulisan ini akan mengkaji diskursus gender dan dakwah di era revolusi industri 4.0 melalui analisis permasalahan bagaimana peran dan konsep dakwah pemberdayaan perempuan terhadap diskursus gender di era digital ini?

\section{Pengertian Gender}

Secara etimologis, kata gender berasal dari bahasa Inggris yang berarti jenis kelamin. Dalam Kamus Besar Bahasa Indonesa (2016), gender diartikan juga sebagai jenis kelamin. Istilah gender merupakan kata dan konsep asing sehingga usaha menguraikan konsep gender dalam konteks Indonesia sangatlah rumit dilakukan. Dilihat dalam kamus, tidak secara jelas dibedakan pengertian kata sex dan gender. Padahal untuk memahami konsep gender harus dibedakan kata gender dengan kata sex (jenis kelamin). Pengertian jenis kelamin (sex) merupakan pensifatan atau pembagian dua jenis kelamin manusia yang ditentukan secara biologis yang melekat pada jenis kelamin tertentu (bentuk anatomi tubuh dan alat-alat reproduksi antara laki-laki dan perempuan berbeda secara biologis, perbedaan ini merupakan kodrat Tuhan dan tidak dapat dipertukarkan satu sama lain). Sedangkan konsep gender merupakan suatu sifat yang melekat pada kaum laki-laki maupun perempuan yang dikonstruksi secara sosial maupun kultural(Echols and Shadily 1983:265). 
Sementara dalam Webster's New World Dictionary, gender diartikan sebagai "the apparent disparity between man and woman in values and behavior" (perbedaan yang tampak antara laki-laki dan perempuan dari segi nilai dan tingkah laku) (Neufeld 1984:561).Sedang menurut Tierney sebagaimana dikutip Yunus (2005:95), gender dapat diartikan pula sebagai suatu konsep yang berupaya membuat perbedaan (distinction) dalam hal peran, perilaku, mentalitas, dan karakteristik emosional antara laki-laki dan perempuan yang berkembang dalam masyarakat.

Di sisi lain, Syamsiah dalam Widanti (2005:32) berpendapat bahwa gender sebagai konsepsi tidak tepat untuk membahas jenis kelamin. Karena jenis kelamin menunjukkan tanda-tanda yang tetap dari seseorang. Sedangkan gender sebagai konsepsi mengacu pada pengertian bahwa lahirnya laki-laki atau perempuan berada dalam waktu, tempat, kultur, bangsa maupun peradaban yang berbeda-beda. Gender adalah interpretasi mental dan kultural terhadap perbedaan jenis kelamin dalam hubungan antara laki-laki dan perempuan. Gender biasanya digunakan untuk menunjukkan pembagian kerja yang dianggap tepat bagi laki-laki dan perempuan.

Adapun secara terminologi, makna sesungguhnya untuk dapat menggambarkan pengertian gender dikatakan oleh Lips (1993) bahwa "gender as cultural expectation for women and men" (gender sebagai harapan-harapan budaya terhadap perempuan dan laki-laki). Hal ini diperkuat dengan pendapat Lindsey (1950) bahwa semua ketetapan masyarakat perihal penentuan seseorang sebagai laki-laki atau perempuan adalah termasuk bidang kajian gender (what a given society defines as masculine or feminine is a component of gender) (Yunus 2005:96).

Sedang Wilson (1989) dalam Yunus (2005:96) mendefinisikan gender sebagai suatu dasar untuk menentukan perbedaan sumbangan laki-laki dan perempuan pada kebudayaan dan kehidupan kolektif sebagai akibat mereka menjadi lakilaki dan perempuan. Adapun Showalter (1989) sebagaimana dikutip Yunus (2005:97) menekankan bahwa gender lebih dari sekedar pembedaan laki-laki dan perempuan ditinjau dari konstruksi sosial dan budaya. Sementara menurut perspektif Kementerian Negara Urusan Peranan Wanita, gender diartikan sebagai interpretasi mental dan kultural terhadap perbedaan kelamin yakni laki-laki dan perempuan. Gender biasanya dipergunakan untuk menunjukkan pembagian kerja yang dianggap tepat bagi laki-laki dan perempuan (Yunus 2005:97).

Sejarah perbedaan gender (gender differences) antara manusia berjenis kelamin laki-laki dan perempuan terjadi melalui proses yang sangat panjang. Dengan demikian, terbentuknya perbedaan-perbedaan gender dikarenakan oleh banyak 
hal, di antaranya dibentuk, disosialisasikan, diperkuat, bahkan dikonstruksi secara sosial dan kultural, melalui ajaran keagamaan maupun Negara (Fakih 1996:9).

Melalui proses panjang sosialisasi gender tersebut akhirnya perbedaaan gender dianggap dan dipahami sebagai ketentuan Tuhan (kodrat yang tidak bisa diubah lagi). Karena proses sosialisasi dan rekonstruksi berlangsung secara mapan dan lama, akhirnya menjadi sulit dibedakan apakah sifat-sifat gender itu dikonstruksi dan dibentuk oleh masyarakat atau kodrat biologis yang ditetapkan Tuhan.

\section{Ideologi Gender}

Secara umum, ideologi dapat dipahami sebagai salah satu ide atau definisi terhadap suatu situasi berdasarkan anggapan dasar tertentu. Secara lebih rinci Abdullah (2003:86) menjelaskan tentang beberapa ciri-ciri yang dijadikan tumpuan pada anggapan dasar pada sebuah ideologi, yaitu sebagai berikut :

1. Ideologi tidak mencerminkan realitas secara utuh tetapi hanya menggambarkan realitas yang persial dan terfragmentasi berdasarkan pada pra konsepsi tertentu yang dimiliki oleh kelompok atau kelas yang berkuasa.

2. Realitas yang terdistorsi dan dicitrakan oleh ideologi itu dikembangkan dan didefinisikan kembali melalui proses sejarah, namun proses sejarah itu juga dipengaruhi oleh pembentukan dan modifikasi ideologi. Dengan demikian, terdapat hubungan timbal balik antara ideologi dan proses sejarah.

3. Ideologi dapat mempengaruhi kehidupan nyata individu dengan mengatur dan memberikan batasan-batasan terhadap aktivitas keseharian manusia. Dengan demikian, ideologi menggunakan kehidupan dan bahasa seharihari sebagai sarana untuk mempengaruhi pengalaman nyata manusia. Karena ideologi merupakan bagian dari kehidupan sehari-hari, maka pengaruh ideologi tersebut tidak dirasakan sebagai suatu paksaan. Dengan cara ini ideologi menyediakan suatu cara hidup dan cara pandang untuk menghadapi dunia nyata, tetapi cara pandang dan cara hidup itu sebenarnya tidaklah sesuai dengan kenyataan.

4. Ideologi memberikan dukugan dan legitimasi terhadap situasi dan aktivitas tertentu yang memberi dukungan kepada kelompok yang dominan. 
Dari beberapa ciri tersebut, Antonio Gramsci (1971) sebagaimana dikutip Abdullah (2003:87) mengatakan bahwa ideologi adalah manifestasi dari bekerjanya sebuah sistem dan proses kekuasaan. Ideologi terbentuk melalui suatu proses sejarah yang panjang sehingga melahirkan suatu keadaan dimana kelompok atau individu yang dikuasai seolah-olah menerima hubungan dominasi yang ada. Ketika kekuasaan itu sedemikian merasuk dan ideologi diterima sebagai bagian yang tidak terpisahkan dari kehidupan sehari-hari maka seakan-akan terjadi "consensus" antara kelompok atau pihak yang tersubordinasi dan penguasaan. Kondisi ini disebut oleh Gramsci sebagai timbulnya ideologi yang hegemonis.Antonio Gramsci mengemukakan bahwa ideologi yang hegemonis merupakan titik klimaks dari kemampuan serangkaian ide ataupun pendapat dari kelompok yang berkuasa untuk mempengaruhi keseluruhan elemen yang ada dalam masyarakat. Ideologi yang hegemonis tersebut menciptakan suatu kepatuhan massa yang "spontan" terhadap ide atau nilai kelompok yang dominan.

Daribeberapakonsep tentangideologidangender tersebut diatas, maka Widanti (2005:32) merumuskan bahwa yang dimaksud ideologi gender adalah segala aturan, nilai, stereotip yang mengatur hubungan perempuan dan laki-laki terlebih dahulu melalui pembentukan identitas feminine dan maskulin, yang menjadi struktur dan sifat manusia, di mana ciri-ciri dasar dan sifat itu dibentuk sejak masa kanak-kanak awal sehingga selalu konservatif dan ketinggalan di belakang perubahan. Ideologi gender ini dapat dibentuk di berbagai tingkat, misalnya tingkat negara, tingkat komunitas, tingkat keluarga dan disosialisasikan melalui berbagai pranata sosial yang dikuasai dan dikendalikan oleh negara maupun kelompok-kelompok yang berkuasa dalam masyarakat.

Meskipun para aktifis gender dan para feminis menyadari bahwa ideologi gender telah menghegemoni manusia berdasarkan perannya sebagai laki-laki dan perempuan. Namun ternyata tidak semua orang menerima ideologi gender. Yunus (2005:94) menyatakan, setidaknya ada 2 hal yang melatarbelakangi alasan atas penolakan terhadap ideologi gender tersebut, yaitu : pertama, mempertanyakan status kaum perempuan pada dasarnya adalah mempersoalkan sistem dan struktur yang telah mapan, bahkan mempertanyakan posisi kaum perempuan pada dasarnya berarti menggoncang struktur dan sistem status quo ketidakadilan tertua dalam masyarakat. Sebagaimana diketahui banyak literatur yang menginformasikan bahwa sebelum turunnya al-Qur'an dan Islam datang, terdapat sekian banyak peradaban (Yunani, Romawi, Cina, India, dll). Dunia juga mengenal agama-agama seperti 
Yahudi, Nasrani, Zoroaster, Hindu, Konghucu, dan sebagainya. Pada masyarakat pra Islam ini, perempuan selalu berada di posisi yang rendah. Sebagaimana diketahui pada puncak peradaban Yunani, perempuan merupakan alat pemenuhan naluri seks laki-laki. Hal ini dapat dilihat dari sisa-sisa peninggalan patung-patung telanjang di Eropa sebagai bukti. Sementara peradaban Romawi menempatkan perempuan berada pada kekuasaan ayahnya (sebelum menikah) dan suaminya (setelah menikah). Kekuasaan ini termasuk kewenangan menjual, mengusir, menganiaya dan membunuh (hal ini berlangsung hingga abad ke V Masehi). Sementara itu, peradaban Hindu dan Cina juga tidak lebih baik, sebagaimana hak hidup seorang perempuan yang bersuami harus berakhir pada saat kematian suaminya (istri harus dibakar hidup-hidup pada saat suaminya dibakar/upacara sati). Tradisi ini baru berakhir pada abad XVII Masehi. Di sisi lain, gambaran tentang kedudukan perempuan dalam agama-agama dunia dijelaskan oleh Sharma (2006) sebagaimana dalam pandangan Yahudi, perempuan hanya difungsikan sebagai alat reproduksi, martabat perempuan sama dengan pembantu. Mereka menganggap perempuan sebagai sumber laknat karena dialah yang menyebabkan Adam terusir dari sorga. Pandangan Kristen pun tidak lebih baik, sepanjang abad pertengahan nasib perempuan sangat memprihatinkan bahkan sampai pada tahun 1805 perundang-undangan Inggris mengakui hak suami untuk menjual istrinya dan sampai tahun 1882 perempuan Inggris belum lagi memilki hak kepemilikan harta benda secara penuh dan hak menuntut ke pengadilan. Tradisi pemahaman kebudayaan dan keagamaan tersebut menurun kepada tradisi intelektual dunia Islam melalui persentuhan (encounter) Islam dengan kultur Yunani, Hellenisme, Sasania-Persia, Yahudi, Kristen dan tentu saja warisan kultur Jahiliyyah yang dipengaruhi Majusi dan Zoroaster. Kedua, karena banyak terjadi kesalahpahaman tentang mengapa masalah kaum perempuan harus dipertanyakan? Kesulitan lain, dengan mendiskusikan soal gender pada dasarnya berarti membahas hubungan kekuasaan yang sifatnya sangat pribadi, yakni menyangkut dan melibatkan individu kita masing-masing serta menggugat privilege yang dimiliki kaum laki-laki dan sedang menikmati selama ini (Yunus 2005:95) .

Oleh karena itu, pemahaman atas konsep dan ideologi gender sesungguhnya merupakan isu mendasar dalam rangka menjelaskan masalah hubungan antara kaum perempuan dan kaum laki-laki, atau masalah hubungan kemanusiaan. 


\section{Sejarah Gerakan Feminisme Secara Global}

Berbicara tentang diskursus gender tentu tidak dapat dilepaskan dari gerakan feminisme. Feminisme berasal dari bahasa Latin, femina atau perempuan. Istilah ini mulai digunakan pada tahun 1890-an, mengacu pada teori kesetaraan laki-laki dan perempuan serta pergerakan untuk memperoleh hak-hak perempuan. Feminisme adalah sebuah gerakan perempuan yang menuntut emansipasi atau kesamaan dan keadilan hak dengan laki-laki. Menurut sumber kepustakaan internasional saat ini sebagaimana dikutip Tong (1998:20), feminisme didefinisikan sebagai pembedaan terhadap hak hak perempuan yang didasarkan pada kesetaraan perempuan dan laki laki. Meskipun, feminisme sebagai gerakan sudah tua, namun baru tahun 60-an dianggap sebagai lahirnya gerakan itu. Gerakan feminisme mendapatkan momentum sejarahnya pada 1960-an dengan menunjukan bahwa sistem sosial masyarakat modern memiliki struktur yang pincang akibat budaya patriarkal yang sangat kental. Marginalisasi peran perempuan dalam berbagai aspek kehidupan, khususnya ekonomi dan politik, merupakan bukti konkret yang diberikan kaum feminis.

Secara historis, Gelombang feminisme di Amerika Serikat mulai lebih keras bergaung pada era perubahan dengan terbitnya buku The Feminine Mystique yang ditulis oleh Betty Friedan pada tahun 1963. Buku ini ternyata berdampak luas, terlebih setelah Betty Friedan membentuk organisasi wanita bernama National Organization for Woman (NOW) pada tahun 1966. Gemanya kemudian merambat ke segala bidang kehidupan. Dalam bidang perundangan, tulisan Betty Friedan berhasil mendorong dikeluarkannya Equal Pay Right (1963) sehingga kaum perempuan bisa menikmati kondisi kerja yang lebih baik dan memperoleh gaji sama dengan laki-laki untuk pekerjaan yang sama, dan Equal Right Act (1964) dimana kaum perempuan mempunyai hak pilih secara penuh dalam segala bidang. Kemudian gerakan tersebut merambat ke Eropa, Kanada dan Australia yang selanjutnya telah menjadi gerakan global dan menggoncang Dunia Ketiga (Tong 1998:20).

Pada tahun 1967 dibentuklah Student for a Democratic Society (SDS) yang mengadakan konvensi nasional di Ann Arbor kemudian dilanjutkan di Chicago pada tahun yang sama, dari sinilah mulai muncul kelompok "feminisme radikal" dengan membentuk Women's Liberation Movement (Gerakan Pembebasan Perempuan) yang lebih dikenal dengan singkatan "Women's Lib”. Women's Lib mengamati bahwa peran kaum perempuan dalam hubungannya dengan kaum laki-laki di 
masyarakat kapitalis terutama Amerika Serikat tidak lebih seperti hubungan yang dijajah dan penjajah. Pada tahun 1968 kelompok ini secara terbuka memprotes diadakannya "Miss America Pegeant" di Atlantic City yang mereka anggap sebagai "pelecehan terhadap kaum wanita dan komersialisasi tubuh perempuan". Gema "pembebasan kaum perempuan" ini kemudian mendapat sambutan di mana-mana di seluruh dunia (Arif 2008:18).

Pada 1975, "Gender, development, dan equality" sudah dicanangkan sejak Konferensi Perempuan Sedunia Pertama di Mexico City. Hasil penelitian kaum feminis sosialis telah membuka wawasan gender untuk dipertimbangkan dalam pembangunan bangsa. Sejak itu, arus pengutamaan gender atau gender mainstreaming melanda dunia.

Memasuki era 1990-an, kritik feminisme masuk dalam institusi sains yang merupakan salah satu struktur penting dalam masyarakat modern. Termarginalisasinya peran perempuan dalam institusi sains dianggap sebagai dampak dari karakteristik patriarkal yang menempel erat dalam institusi sains. Tetapi, kritik kaum feminis terhadap institusi sains tidak berhenti pada masalah termarginalisasinya peran perempuan. Kaum feminis telah berani masuk dalam wilayah epistemologi sains untuk membongkar ideologi sains yang sangat patriarkhal. Dalam kacamata eko-feminisme, sains modern merupakan representasi kaum laki-laki yang dipenuhi nafsu eksploitasi terhadap alam. Alam merupakan representasi dari kaum perempuan yang lemah, pasif, dan tak berdaya. Dengan relasi patriarkhal demikian, sains modern merupakan refleksi dari sifat maskulinitas dalam memproduksi pengetahuan yang cenderung eksploitatif dan destruktif (Tong 1998:366).

Walaupun pendapat feminis bersifat pluralistik, namun satu hal yang menyatukan mereka yaitu adanya keyakinan bahwa masyarakat dan tatanan hukum bersifat patriarkhal. Sebagaimana dalam kutipan Ridjal (1993:13), Riffaat Hasan mencatat bahwa struktur masyarakat patriarkhal ini menyimpan tiga asumsi dasar. Pertama, manusia pertama adalah laki-laki, dan perempuan diciptakan darinya, sehingga ia adalah makhluk sekunder. Kedua, walaupun perempuan adalah makhluk kedua dalam proses penciptaan, ia adalah makhluk pertama dalam perbuatan dosa, dialah yang menggoda Adam sehingga akhirnya terusir dari sorga. Ketiga, perempuan bukan saja dari laki-laki tetapi juga untuk laki-laki. Asumsi ketiga ini berimplikasi pada munculnya anggapan bahwa perempuan tidak mempunyai hak untuk mendefinisikan status, hak dan martabatnya, kecuali apa yang disediakan 
kaum laki-laki untuknya. Kehadiran perempuan di dunia ini bersifat instrumental bagi kepentingan laki-laki dan bukan fundamental.

Aturan hukum yang dikatakan netral dan objektif sering kali hanya merupakan kedok terhadap pertimbangan politis dan sosial yang dikemudikan oleh ideologi pembuat keputusan, dan ideologi tersebut tidak untuk kepentingan perempuan. Sifat patriarkhal dalam masyarakat dan ketentuan hukum merupakan penyebab ketidakadilan, dominasi dan subordinasi terhadap perempuan. Berbagai studi lintas budaya menunjukkan bahwa perempuan selalu berada dalam posisi tersubordinasi. Oleh karena subordinasi perempuan tidak dapat dijelaskan dengan perbedaan jenis kelamin, maka kemudian lahirlah konsep gender. Menurut Gailey (1987) sebagaimana dikutip Ridjal (1993) bahwa secara garis besar teori yang dikembangan untuk menjelaskan hierarkhi gender dapat dibagi menjadi empat kelompok besar, yaitu teori adaptasi awal, teori teknik-lingkungan, teori sosiobiologi dan teori struktural.

Menurut teori adaptasi awal, pada prinsipnya hierarki gender terbentuk berdasarkan adaptasi awal manusia yaitu terjadinya dasar pembagian kerja secara seksual, sekaligus dasar subordinasi perempuan. Teori adaptasi awal dibangun berdasarkan asumsi : (1). Berburu sangat penting bagi kelangsungan hidup nenek moyang kita. (2). Laki-lakilah yang hampir selalu melakukan kegiatan berburu. (3). Perempuan tergantung kepada laki-laki untuk memperoleh daging. (4). Lakilaki berbagi daging buruannya terutama dengan istri-istrinya dan anak-anaknya. (5). Sekali pola pembagian peran berdasarkan jenis kelamin ini terbentuk, dia tidak berubah hingga sekarang. Sedangkan teori teknik-lingkungan, menjelaskan bahwa hierarki gender didasarkan pada apa yang dianggap sebagai hukum alam, yaitu kelangkaan sumber daya dan tekanan penduduk. Teori ini menjelaskan bahwa upaya untuk mengontrol pertumbuhan penduduk sudah menjadi masalah sejak zaman dulu. Dalam konteks ini subordinasi perempuan berakar pada peran reproduktif mereka. Adapun adanya hierarki gender menurut teori sosiobiologi, dikarenakan bahwa dominasi laki-laki muncul sebagai akibat seleksi alam, terutama yang berkaitan dengan ketahanan tubuh. Sementara teori struktural, menjelaskan hierarki gender didasarkan pada asumsi bahwa subordinasi perempuan adalah kultural sekaligus universal. Kelompok pertama berpendapat bahwa pembagian bidang kehidupan menjadi arena publik dan domestik ini dianggap universal. Sedangkan kelompok lain dari kategori teori struktural berargumentasi bahwa subordinasi perempuan itu kultural, akan tetapi ia berakar pada pembagian kerja 
berdasarkan gender. Pembagian kerja ini bersumber pada asosiasi simbolik yang universal antara perempuan dengan alam (nature) dan laki-laki dengan budaya (culture) (Ridjal 1993:33-34).

Hak Asasi Perempuan adalah Hak Asasi Manusia. Deklarasi Hak Asasi Manusia yang dicanangkan oleh PBB pada tahun 1948 berisi pesan bahwa setiap anak manusia dilahirkan dengan martabat yang sama dan punya hak sama untuk dihormati kebebasannya. Hal ini berlaku tanpa membedakan ras, etnis, agama, atau bangsa. Namun dalam tataran pragmatis bagi perempuan, kebebasan, martabat dan kesetaraan masih sering dilanggar, baik oleh hukum yang berlaku maupun oleh ketentuan adat dan tradisi yang berlaku baginya. Oleh karena itu, tidaklah mungkin memperjuangkan hak asasi perempuan terpisah dari perjuangan memperoleh kesetaraan antara laki-laki dan perempuan.

Dengan demikian, dalam usaha menghentikan kekerasan berbasis gender, perempuan dari berbagai negara yang hadir dalam Konferensi Dunia tentang HAM di Vienna (1993) serentak menyatakan bahwa tidak cukup kalau mekanisme HAM hanya disebutkan berlaku untuk semua, laki-laki dan perempuan. Para feminis menuntut kekerasan berbasis gender menjadi agenda pembicaraan setiap kali pertemuan internasional membuat perjanjian-perjanjian tentang HAM. Gerakan perempuan juga menuntut untuk memonitor dan memperkuat usaha agar isu kekerasan terhadap perempuan termasuk dalam perjanjian-perjanjian internasional HAM. Solidaritas perempuan inilah yang telah mendorong terjadinya transformasi konsep HAM sesuai kebutuhan perempuan.

Dalam perjalanan sejarah gerakan perempuan untuk memperjuangkan hakhak kesetaraan gender, hingga saat ini berbagai konferensi dunia tentang perempuan telah diselenggarakan, di antaranya adalah Konferensi Perempuan pertama di Meksiko tahun 1975, selanjutnya di Kopenhagen, Denmark, tahun 1980; kemudian Konferensi di Nairobi, Kenya, tahun 1985, dan Konferensi di Beijing, China tahun 1995. Adapun tahun 2020 disebut sebagai tahun yang luar biasa untuk kesetaraan gender. Hal ini sebagaimana diungkapkan direktur eksekutif Perempuan PBB, Phumzile Mlambo-Ngcuka karena merupakan salah satu momentum peringatan ke 25 Deklarasi dan Platform Aksi Beijing. Di samping itu juga tepat merupakan 10 tahun sejak berdirinya Perempuan PBB, dan peringatan 20 tahun resolusi Dewan Keamanan PBB 1325 tentang perempuan, perdamaian dan keamanan (CNN Indonesia 2020). 
Dalam tataran global, perempuan di seluruh dunia mengangkat isu-isu yang menjadi kepedulian perempuan. Salah satu yang dianggap sebagai isu yang dialami perempuan di berbagai belahan dunia adalah bahwa diskriminasi terhadap perempuan masih marak dilakukan di hampir setiap negara. Isu diskriminasi terhadap perempuan diangkat sebagai isu global di dalam Konferensi Dunia tentang Perempuan di Meksiko tahun 1975. Konferensi di Meksiko menyepakati untuk menyusun naskah tentang penghapusan diskriminasi terhadap perempuan dan membahasnya di Sidang Umum PBB. Hasilnya, setelah tahun 1975 Sidang Umum PBB mengumumkan International Decade of Women, Tahun 1979 PBB menetapkan berlakunya Konvensi Penghapusan Segala Bentuk Diskriminasi terhadap Perempuan (Sadli 2010:34).

Saat ini hampir setiap Negara memiliki perundang-undangan antidiskriminasi, yang menguntungkan kaum perempuan terutama kelas menengah dan yang berpendidikan. Hal ini dapat dilihat bahwa jumlah anak perempuan yang sekolah terus meningkat; control mereka terhadap jumlah anak yang dikehendaki serta pilihan kontrasepsi juga menguat. Revolusi di Zimbabwe, Angola, Mozambique, dan Nicaragua memasukkan pembebasan perempuan sebagai bagian dalam ideologi mereka. Bahkan hampir setiap universitas besar kini membuka bidang Women Study. Bidang dan Biro urusan perempuan sudah dibentuk di hampir setiap organisasi internasional maupun lokal (Fakih 1996:108).

Meski demikian, perubahan secara kuantitatif tersebut ternyata belum mampu merubah posisi kaum perempuan secara kualitatif. Dengan kata lain bahwa dengan berubahnya undang-undang, hak ekonomi serta akses terhadap berbagai aspek bagi kaum perempuan tidak sendirinya secara fundamental merubah posisi mereka. Hukum diskriminasi bisa jadi tepat secara teoretik untuk diperjuangkan, namun pandangan masyarakat, kultur dan tafsiran agama tetap melanggengkan diskriminasi terhadap perempuan (Fakih 1996:108).

\section{Potret Diskursus Gender di Indonesia}

Perbedaan gender sebenarnya bukan merupakan problem jika tidak menimbulkan ketimpangan gender. Namun realitasnya, ternyata perbedaan gender (gender differences) seringkali melahirkan ketidakadilan gender (gender inequalities). Perbedaan gender ini ternyata telah mengakibatkan lahirnya sifat dan stereotype yang sebetulnya merupakan konstruksi ataupun rekayasa sosial yang pada akhirnya terkukuhkan menjadi kodrat cultural, dianggap masyarakat sebagai 
ketentuan kodrati atau bahkan ketentuan Tuhan. Melalui proses yang panjang, akhirnya manifestasi gender mengkondisikan beberapa posisi perempuan sebagai berikut (Fakih 1996:147-151) :

1. Perbedaan dan pembagian gender yang mengakibatkan, termanifestasi dalam posisi subordinasi kaum perempuan di hadapan laki-laki.

2. Secara ekonomis, perbedaan dan pembagian gender juga melahirkan proses marginalisasi perempuan. Proses marginalisasi perempuan terjadi dalam kultur, birokrasi maupun program-program pembangunan.

3. Perbedaan dan pembagian gender juga membentuk penandaan atau stereotype terhadap kaum perempuan yang berakibat pada penindasan terhadap mereka.

4. Perbedaan dan pembagian gender juga membuat kaum perempuan bekerja lebih keras dengan memeras keringat jauh lebih panjang (double burden).

5. Perbedaan gender juga melahirkan kekerasan dan penyiksaan (violence) terhadap kaum perempuan, baik secara fisik maupun psikologis (mental).

6. Perbedaan dan pembagian gender dengan segenap manifestasinya tersebut juga mengakibatkan tersosialisasinya citra posisi, kodrat dan penerimaan nasib perempuan yang ada. Semua ini juga merupakan proses penjinakkan (cooptation) peran gender perempuan.

Indonesia sebagai negara peserta dalam Konferensi Dunia tentang Perempuan di Meksiko tahun 1975 mempunyai tanggung jawab legal dan moral melaksanakan prinsip dan ketentuan dalam Konvensi Wanita, antara lain menyesuaikan undangundang yang ada agar tidak bertentangan dengan konvensi yang diratifikasi. Indonesia meratifikasi hasil Sidang Umum PBB yang menetapkan berlakunya Konvensi Penghapusan Segala Bentuk Diskriminasi terhadap Perempuan tersebut dengan UU No. 7/1984. Konvensi ini disingkat sebagai Konvensi Wanita dan disebut CEDAW (Convention on the Elimination of All Types of Discrimination against Women)(Sadli 2010:34). CEDAW merupakan alat penting dalam upaya pemberdayaan perempuan dan keadilan gender di berbagai lingkup kehidupan. Selain itu, Indonesia juga mempunyai tanggung jawab untuk mensosialisasi isi CEDAW kepada berbagai pihak dalam masyarakat dan menulis laporan kepada Komite CEDAW tantang kemajuan dan hambatan yang dialami dalam menghapus diskriminasi terhadap perempuan(Sadli 2010:35). 
Sebagaimana Konferensi di Beijing, China tahun 1995 dengan tema "Kesetaraan, Pembangunan dan Perdamaian". Ketiga komponen tersebut saling terkait sehingga perlu mendapat perhatian sama seriusnya oleh setiap negara yang telah menandatangani kesepakatan Beijing. Bagi Indonesia, hal ini berarti bahwa upaya pemberdayaan perempuan telah diberi landasan moral dan legal.

Meski berbagai program pemberdayaan perempuan dalam rangka penyetaraan gender sudah diupayakan berbagai pihak, namun hingga momentum peringatan Deklarasi dan Platform Aksi Beijing sudah berjalan 25 tahun, bertepatan juga dengan peringatan 10 tahun berdirinya Perempuan PBB dan 20 tahun resolusi Dewan Keamanan PBB tentang perempuan, perdamaian dan keamanan pada tahun 2020. Ketimpangan berbasis gender masih sering ditemukan dalam implementasi prinsip dan norma kesetaraan gender di Indonesia. Sebagaimana diungkapkan Rohika Kurniadi Sari, Asisten Deputi Pemenuhan Hak Anak atas Pengasuhan, Keluarga, dan Lingkungan di Kementerian Pemberdayaan Perempuan dan Perlindungan, menjelaskan bahwa kesetaraan antara perempuan dan lelaki masih menjadi pekerjaan rumah untuk diselesaikan. Dalam diskusi menyambut hari Perempuan Internasional yang digelar di Jakarta, Rohika menekankan bahwa sampai saat ini masih banyak hal-hal yang belum setara antara kaum hawa dengan kaum adam. Mulai dari kekerasan, kemudian masih banyaknya perkawinan anak, hingga tingginya angka perceraian (Wardah 2020).

Masih rendahnya tingkat kesetaraan gender di Indonesia juga dinyatakan Menteri Pemberdayaan/Perempuan dan Perlindungan Anak (PPPA), I Gusti Ayu Bintang Darmawati. Hal ini tercermin dari indeks kesetaraan gender yang dirilis Badan Program Pembangunan PBB (UNDP) menunjukkan bahwa Indonesia berada pada peringkat 103 dari 162 negara, atau terendah ketiga se-ASEAN. Indeks Pembangunan gender Indonesia per 2019 berada di angka 91,07 dan per 2020 di angka 91,06 (Statistik 2020a). Kemudian Indeks Pemerdayaan Gender (IDG) pada tahun 2019 sebesar 75,24 dan tahun 2020 sebesar 75,57 (Statistik 2020b).

Berdasarkan data tersebut, menunjukkan bahwa realita di lapangan saat ini, perempuan masih tertinggal di belakang laki-laki, baik di bidang pendidikan, kesehatan, ekonomi, hingga keterwakilan dalam politik. Ketimpangan gender pun semakin terlihat di masa pandemi covid-19. Perempuan sebagai kelompok rentan yang seharusnya mendapatkan perlindungan, harus menghadapi berbagai tantangan. Seperti, beban sebagai pendidik, pencari nafkah, hingga ancaman kekerasan rumah tangga Menurut Bintang, kesetaraan gender berdampak langsung 
pada target kesetaraan pembangunan. Rumitnya perwujudan kesetaraan gender di Indonesia berkaitan dengan timpangnya akses partisipasi kontrol, serta kesempatan memperoleh manfaat antara perempuan dan laki-laki. Salah satunya dipicu nilai patriarki dan konstruksi sosial di masyarakat (Winahyu 2020)

Pemerintah dan masyarakat perlu mengatasi ketimpangan ini demi meningkatkan akses dan perlindungan bagi perempuan di Indonesia, untuk menjaga citra dan upaya Indonesia dalam mempromosikan gender di level internasional. Menurut penuturan Rohika sebagaimana dikutip Wardah (2020)bahwa pemerintah Indonesia telah menetapkan 2045 sebagai Tahun Indonesia Emas, sebagai target terwujudnya kesetaraan antara perempuan dan lelaki. Rohika menambahkan bahwa kesetaraan adalah bagaimana perempuan dan lelaki sama-sama mendapatkan empat hal, yakni akses, partisipasi, kontrol, dan mendapatkan manfaat. Kesetaraan antara perempuan dan lelaki perlu dibangun mulai dari keluarga. Untuk membangun kesetaraan antara perempuan dan lelaki dalam keluarga dimulai dengan kesetaraan dalam pendidikan, kemudian kesetaraan dalam bidang kesehatan dan kesetaraan dalam berpendapat.

Adapun menurut Prajuli (2021) di antara cara yang dapat ditempuh untuk mewujudkan kesetaraan gender adalah :

Pertama, pemerintah perlu aktif meningkatkan kesadaran gender di kalangan elite politik dan aparat negara. Penghambat utama kesadaran gender di level negara adalah pola pikir patriarki atau maskulin yang berkembang di kalangan elite politik dan aparat pemerintah.

Kedua, pemerintah juga harus memperbanyak hukum dan peraturan yang pro kesetaraan gender untuk mewujudkan hubungan gender yang berkeadilan. Di sisi lain, masyarakat perlu secara berkesinambungan menyuarakan dan mendesak pemerintah untuk lebih peduli pada persoalan gender.

Ketiga, masyarakat juga perlu menyelenggarakan pendidikan dan/atau kegiatan lainnya yang dapat meningkatkan kesadaran gender anggota masyarakat lainnya.

\section{Dakwah Pemberdayaan Perempuan di Era Revolusi Industri 4.0}

Pelanggengan posisi subordinasi, stereotype, dan kekerasan terhadap perempuan secara tidak sadar juga dijalankan oleh ideologi dan kultur patriarkhi. Ideologi ini menghegemoni mainstream laki-laki maupun perempuan, juga dalam tafsir agama yang sangat mempengaruhi kebijakan negara dan birokrasi pembangunan. 
Memperjuangkan perempuan tidak sama dengan perjuangan perempuan melawan laki-laki. Karena persoalan penindasan terhadap perempuan bukanlah persoalan kaum laki-laki, melainkan persoalan sistem dan struktur ketidakadilan masyarakat (Fakih 1996:151).

Oleh karena itu, perlu adanya gerakan transformasi perempuan, yaitu suatu proses gerakan untuk menciptakan hubungan antar sesama manusia yang secara fundamental lebih baik dan lebih adil. Fakih menawarkan beberapa alternative agenda yang perlu dilakukan dalam rangka gerakan transformasi perempuan di antaranya adalah (Fakih 1996:152) :

1. Melawan hegemoni yang merendahkan perempuan dengan cara melakukan dekonstruksi ideologi, melakukan pendidikan kritis yang bertujuan untuk membangkitkan kesadaran kritis gender (gender critical consciousness), yakni kesadaran akan ideologi hegemoni dominan dan kaitannya dengan penindasan gender.

2. Melawan paradigma developmentalisme yang berasumsi bahwa keterbelakangan perempuan disebabkan karena mereka tidak berpartisipasi dalam pembangunan. Dengan demikian, perjuangan perempuan termasuk senantiasa mempertanyakan dominasi elit yang menggunakan pengetahuan dan diskursus pembangunan serta hegemoni kapitalisme dan modernisasi.

Adapun upaya pemecahan masalah gender, khususnya di era revolusi industri 4.0 saat ini dapat dilakukan di antaranya dengan membuat program aksi yang melibatkan perempuan agar mereka mampu mengatasi masalahnya sendiri. Selain itu juga melaksanakan pendidikan dengan mengaktifkan berbagai organisasi atau komunitas perempuan. Perempuan juga perlu memberikan pesan penolakan secara tegas terhadap berbagai bentuk kekerasan dan pelecehan. Hingga akhirnya perlu juga dilakukan studi dalam berbagai bentuk ketidakadilan gender dan manifestasinya baik di masyarakat, negara maupun rumah tangga untuk melakukan advokasi guna mencapai perubahan kebijakan hukum dan aturan pemerintah yang dinilai tidak adil terhadap perempuan (Fakih 1996:154).

Pemberdayaan Perempuan diera revolusi 4.0 ini, dapat dikemas melalui berbagai program dakwah yang menarik, kreatif dan inovatif. Dakwah pada dasarnya adalah sebuah proses tranformasi dan rekayasa sosial. Dakwah sering dikaitkan dengan usaha merubah situasi, dari yang kurang baik menjadi lebih baik dan sempurna, baik yang ditujukan untuk perorangan maupun masyarakat. Dengan begitu maka 
dakwah tidak sekedar usaha peningkatan pemahaman keagamaan dan pandangan hidup saja, tetapi juga mencakup sasaran yang lebih luas, yaitu pelaksanaan ajaran Islam secara menyeluruh dalam berbagai segi kehidupan (Puteh and Saefullah 2006:5).

Di era revolusi industri 4.0 saat ini, dakwah dapat berperan dalam mengajak perempuan untuk berdaya dan mengembangkan potensinya melalui program dakwah pemberdayaan perempuan. Misalnya dakwah pemberdayaan perempuan dengan memberikan pelatihan atau pendidikan perempuan berbasis komunitas. Hal ini sebagai upaya mewujudkan perempuan yang berdaya dalam menjalankan tugas dan perannya secara proporsional dan professional. Pemberdayaan perempuan melalui pelatihan atau pendidikan berbasis komunitas yang dikemas dalam program dan kegiatan dakwah diharapkan bisa mengajak perempuan untuk menjadi pribadi yang positif dan mampu mengembangkan potensi dirinya secara aktif dan kreatif, sehingga bisa menjalankan perannya sebagai istri yang mampu memanaj rumah dengan baik, sebagai ibu yang mampu menjadi pendidik pertama dan utama putra/ putrinya, sebagai individu yang berpotensi sehingga mampu menghasilkan karya produktif atau berkarier agar mandiri secara financial serta sebagai pribadi yang berakhlakul karimah sehingga mampu menjadi teladan dan agen perubahan sosial bagi lingkungannya.

Dakwah pemberdayaan perempuan di era revolusi 4.0 tentu saja harus dilihat segmen dan kebutuhan dari setiap komunitas atau kelompok perempuan yang dibina. Hal ini dapat dilakukan dengan membentuk komunitas-komunitas perempuan yang bertujuan untuk memberdayakan perempuan dalam berbagai bidang di antaranya :

1. Program dakwah pemberdayaan perempuan melalui komunitas remaja putri atau komunitas pre married counseling (konseling pra nikah). Program dakwah konseling pra nikah melalui pendidikan/pelatihan komunitas remaja putri ini, selain dibekali tentang ilmu-ilmu dalam memanaj diri dan rumah tangga, juga dibekali ilmu-ilmu pengembangan potensi diri agar mampu mandiri dan produktif secara financial tetapi tanpa harus keluar dari orbit dan melupakan kewajiban sebagai istri dan ibu.

2. Program dakwah pemberdayaan perempuan bagi komunitas ibu rumah tangga yang dibina untuk dibekali ilmu menjadi pendidik pertama bagi anak-anaknya yang akan memberikan dampak penguatan moralitas 
generasi bangsa, ilmu manajemen keluarga islami dan ilmu-ilmu pengembangan diri yang nantinya bisa meningkatkan potensinya agar mampu menghasilkan karya yang produktif untuk bisa mandiri.

3. Program dakwah pemberdayaan perempuan bagi komunitas perempuan karier yang dibina tentang ilmu manajemen waktu dan keluarga islami. Agar mampu mengatur waktu sebaik mungkin untuk bisa produktif mengembangkan diri tanpa harus melupakan kewajiban dan perannya di dalam rumah tangga sebagai istri dan ibu.

\section{Kesimpulan}

Diskursus gender bagai polemik yang terus bergulir. Membincang persoalan gender secara global akan menemui beragam model gerakan perempuan karena isu gender meliputi berbagai aspek kehidupan, baik politik, ekonomi, pendidikan, budaya, media, pekerjaan dan sebagainya. Belum lagi ditilik dari aspek pandangan lintas agama. Setiap agama mempunyai pandangan dan perspektif yang berbeda. Hal ini tentu berdampak pada peran setiap agama dalam memposisikan perempuan. Meski pemikiran feminis terkait dengan gender itu pluralistik, namun pada dasarnya mereka sepakat akan satu keyakinan yang menyatukan mereka bahwa masyarakat dan tatanan hukum yang bersifat patriarkhal inilah yang menempatkan perempuan pada posisi marjinal dan tersubordinasi.

Sedangkan dalam perspektif Islam, pada dasarnya Allah tidak membedakan laki-laki dan perempuan secara diskriminatif. Keadilan gender yang disampaikan al-Qur'an mengandung makna bahwa yang dimaksud dengan adil bukan berarti sama rata dalam berbagai hal antara hak perempuan dan laki-laki. Namun adil berarti proporsional, sesuai dengan hak dan kewajiban. Laki-laki dan perempuan memang makhluk yang berbeda karena diciptakan untuk tujuan yang berbeda. Namun sesungguhnya perbedaan tersebut dimaksudkan agar perempuan dapat saling melengkapi untuk bisa hidup berpasangan.

Peran dakwah dalam diskursusgender dapat dilakukan melalui program dakwah pemberdayaan perempuan melalui pendidikan atau pelatihan berbasis komunitas. Di era revolusi industri 4.0 saat ini diperlukan pembinaan kaum perempuan untuk dapat menjalankan perannya secara professional namun tidak harus keluar pada orbitnya. Dengan demikian, perempuan perlu mencari ilmu sebanyak-banyaknya, anak perempuan perlu sekolah yang setinggi-tingginya. Karena niscaya semua ilmunya akan bermanfaat dan digunakan sepanjang kehidupannya. Para perempuan 
berhak mengembangkan diri dan potensinya untuk mampu produktif dan berkarya serta mandiri secara finansial di berbagai bidang sesuai dengan passion dan bakatnya. Namun harus tetap mampu berjalan di koridor nilai-nilai Islam tanpa harus mengingkari perannya sebagai istri dan ibu. Satu perempuan yang terdidik dengan baik akan mampu melahirkan sebuah generasi yang tangguh dan pada akhirnya akan mampu membentuk sebuah peradaban khairah ummah.

\section{Daftar Pustaka}

Abdullah, Irwan, ed. (2003). Sangkan Paran Gender. Yogyakarta: Pustaka Pelajar. Arif, Syamsuddin. (2008). Orientalis Dan Diabolisme Pemikiran. Jakarta: Gema Insani.

Badan Pengembangan dan Pembinaan Bahasa. (2016). Kamus Besar Bahasa Indonesia. Kementerian Pendidikan dan Kebudayaan Republik Indonesia.

CNN Indonesia. (2020). "Hari Perempuan Internasional: Sejarah Dan Ragam Tuntutan."

Echols, John M., and Hassan Shadily. (1983). Kamus Inggris-Indonesia. Jakarta: Gramedia.

Fakih, Mansour. (1996). Analisis Gender Dan Transformasi Sosial. Yogyakarta: Pustaka Pelajar.

Gandhi, Mahatma. (2002). Kaum Perempuan Dan Ketidakadilan Sosial. Yogyakarta: Pustaka Pelajar.

Neufeld, Victory, ed. (1984). Webster's New World Dictionary. New York: Webster's New World Clevenland.

Prajuli, Wendy Andhika. (2021). "Kebijakan Pro Kesetaraan Gender Di Indonesia : Maju Di Luar Negeri, Mundur Di Dalam Negeri." The Conversation.

Puteh, M. Jakfar, and Saefullah, eds. (2006). Dakwah Tekstual Dan Kontekstual: Peran Dan Fungsinya Dalam Pemberdayaan Ekonomi Umat. Yogyakarta: AK Group.

Ridjal, Fauzie, ed. (1993). Dinamika Gerakan Di Indonesia. Yogyakarta: PT. Tiara Wacana.

Sadli, Saparinah. (2010). Berbeda Tetapi Setara: Pemikiran Tentang Kajian Perempuan. Jakarta: PT. Kompas Media Nusantara. 
Sharma, Arvind, ed. (2006). Perempuan Dalam Agama-Agama Dunia. Yogyakarta: SUKA Press.

Statistik, Badan Pusat. (2020a). "Indeks Pembangunan Gender (IPG) 2019-2020." Retrieved (https://www.bps.go.id/indicator/40/463/1/indeks-pembangunangender-ipg-.html).

Statistik, Badan Pusat. (2020b). "Indeks Pemberdayaan Gender (IDG) 2019-2020." Retrieved (https://www.bps.go.id/indicator/40/468/1/indeks-pemberdayaangender-idg-.html).

Tong, Rosemarie Putnam. (1998). Feminist Thought: Pengantar Paling Komprehensif Kepada Aliran Utama Pemikiran Feminis. edited by A. P. P. (Terj.). Yogyakarta: Jalasutra.

Wardah, Fathiyah. (2020). "Ketidaksetaraan Gender Masih Tinggi Di Indonesia." VOAIndonesia. Retrieved(https://www.voaindonesia.com/a/ketidaksetaraangender-masih-tinggi-di-indonesia-/5316082.html).

Widanti, Agnes. (2005). Hukum Berkeadilan Gender. Jakarta: PT. Kompas Media Nusantara.

Winahyu, Atikah Ishmah. (2020). "Kesetaraan Gender Di Indonesia Masih Rendah.” Media Indonesia.

Yunus, Mardiyah. (2005). "Perempuan Dalam Perspektif Gender (Upaya Pemberdayakan Perempuan Dalam Segala Bidang)." Menara TEbuireng: Jurnal Ilmu-Ilmu Keislaman 1:95. 